\title{
Histochemical Studies of Pancreas in Prenatal Goat (Capra hircus)
}

\author{
Dharmendra Singh", Ajay Prakash, M.M. Farooqui, Sri Prakash Singh, \\ Satish K. Pathak and Vijay Kumar \\ Department of Anatomy, College of Veterinary Science \& A.H., DUVASU, \\ Mathura-281001, U.P., India \\ *Corresponding author
}

A B S T R A C T

Keywords

Pancreas,

Histochemical

Study, Goat.

Article Info

Accepted:

17 June 2017

Available Online:

10 August 2017
The present study was conducted on the 24 goat foeti of either sex ranging from 42 days to full term gestation. In all the structural components (Tubules cells, bud cells, islets cells, acinar cells, pancreatic duct cells, mesenchymal cells, stromal tissue and wall of blood vessels) of foetal goat pancreas showed positive reaction for glycogen, mucopolysacharides, acid mucopolysacharides and lipids in mid and late prenatal period except in the stromal tissue where lipids were almost absent. In both groups the reaction for alkaline phosphate in mesenchymal cells, islets, acinar cells, stromal tissue and wall of blood vessels showed positive reaction whereas these showed negative reaction of acid phosphatase.

\section{Introduction}

The pancreas is the unique gland having exocrine and endocrine functions. At the time of histogenesis of foetal pancreas their cellular composition changes as age advance. It was noticed a decrease in the amount of glycogen in acinar cell buds with the advancement of foetal age in human (Conklin, 1962) but literature is scanty in foetal goat pancreas. Therefore, present study was undertaken to see the reactions in different components of pancreas in prenatal goat.

\section{Materials and Methods}

The present study was conducted on the 24 goat foeti of either sex ranging from 42 days to full term gestation. The approximate age of foeti was estimated by using the formula derived by Singh et al., (1979) in goat. The material was divided into early prenatal ( 0 to 50 days), mid prenatal (51 to 100 days) and late prenatal (101 to till term) periods. For this study tissue sample were collected and fixed in neutral formalin. This tissue was processed through alcohol- benzene- paraffin embedding technique and 5 to 6 micron and stained with following methods.

\section{Results and Discussion}

In all the histological components of foetal goat pancreas except the cells of islets of Langerhans and acini the reaction for glycogen in late prenatal period was similar as 
it was found in mid prenatal period. It was mild to moderately positive in the stromal tissue, moderately positive in the cytoplasm of tubules cells, pancreatic ducts cells and mesenchymal cells, moderate to intensely positive in the cytoplasm of buds cells and intensely positive in the wall of blood vessels (Fig. 1). The cytoplasm of goat foetal acinar cells exhibited intense and moderate positive reaction for glycogen in mid and late prenatal periods, respectively. In the present study the cytoplasm of islets cells showed moderate and moderate to intensely positive for glycogen in mid and late prenatal period, respectively.

The cytoplasm of foetal goat pancreatic mesenchymal cells, tubular cells, bud cells, acinar cells and pancreatic duct cells showed mild, mild to moderate, moderate, mild to moderate and moderate reaction for PAS positive substances in both mid and late prenatal periods (Fig. 2). In the present study the PAS positive reaction in the cytoplasm of islets cells and in stromal tissue was relatively more in late prenatal period than mid prenatal period.

The reaction for acid mucopolysaccharides in all foetal goat pancreatic components in late prenatal period was similar to the mid prenatal period. In the cytoplasm of mesenchymal cells, tubules cells, bud cells islets cells, acinar cells and pancreatic duct cells, stromal tissue and blood vessels was intense, moderate, moderate, moderate to intense, mild to intense, moderate, moderate to intense and intense respectively in both groups (Fig. 3).

In goat foetal pancreas of mid and late prenatal period the mesenchymal cells, tubules cells, bud cells, islets cells, pancreatic duct cells and the wall of blood vessels showed mild, mild, moderate, mild, mild to moderate and moderately positive reaction respectively for lipids. The acinar cells had relatively more lipid in late prenatal period than mid prenatal goat where the reaction was mild in mid prenatal period and moderate in late prenatal period. In stromal tissue the lipids were almost absent where trace of these substances was present only in mid prenatal period (Fig. 4).

In all histological component of foetal goat pancreas the reaction for alkaline phosphate in late prenatal period was similar to mid prenatal. The mesenchymal cells, islets and acinar cells exhibited mild reactions. The stromal tissue and wall of blood vessels showed mild to moderate and moderate amount of this enzyme, respectively. The alkaline activity was absent in the cells of pancreatic tubules, buds and ducts of foetal goats. The nuclei of the cells of all component of goat foetal pancreas exhibited mild feulgen reaction in mid and late prenatal periods (Fig. 5). The acid Phosphatase activity could not be observed in the pancreas of goat foetus at mid and late prenatal periods.

In all the histological components of foetal goat pancreas except the cells of islets of Langerhans and acini the reaction for glycogen in late prenatal period was similar as it was found in mid prenatal period. It was mild to moderately positive in the stromal tissue, moderately positive in the cytoplasm of tubules cells, pancreatic ducts cells and mesenchymal cells, moderate to intensely positive in the cytoplasm of buds cells and intensely positive in the wall of blood vessels. Like and Orci (1972) and Conklin (1962) in the foetal pancreas of man showed the presence of glycogen in primitive tubules cells and in large ducts. Moreover, Meshram et al., (2002) in kids reported the positive reaction of glycogen in interlobular and intra acinar blood vessels along with moderate amount of this substance in inter acinar septa. The cytoplasm of goat foetal acinar cells exhibited intense and moderate positive reaction for glycogen in mid and late prenatal periods, respectively. 
Fig.1 Section of 118 days old goat foetal pancreas showing intense glycogen reaction in acini (a), moderate reaction in duct cells (b), mild to moderate reaction in stromal tissue (c),

and moderate to intense reaction in islets cells (d)

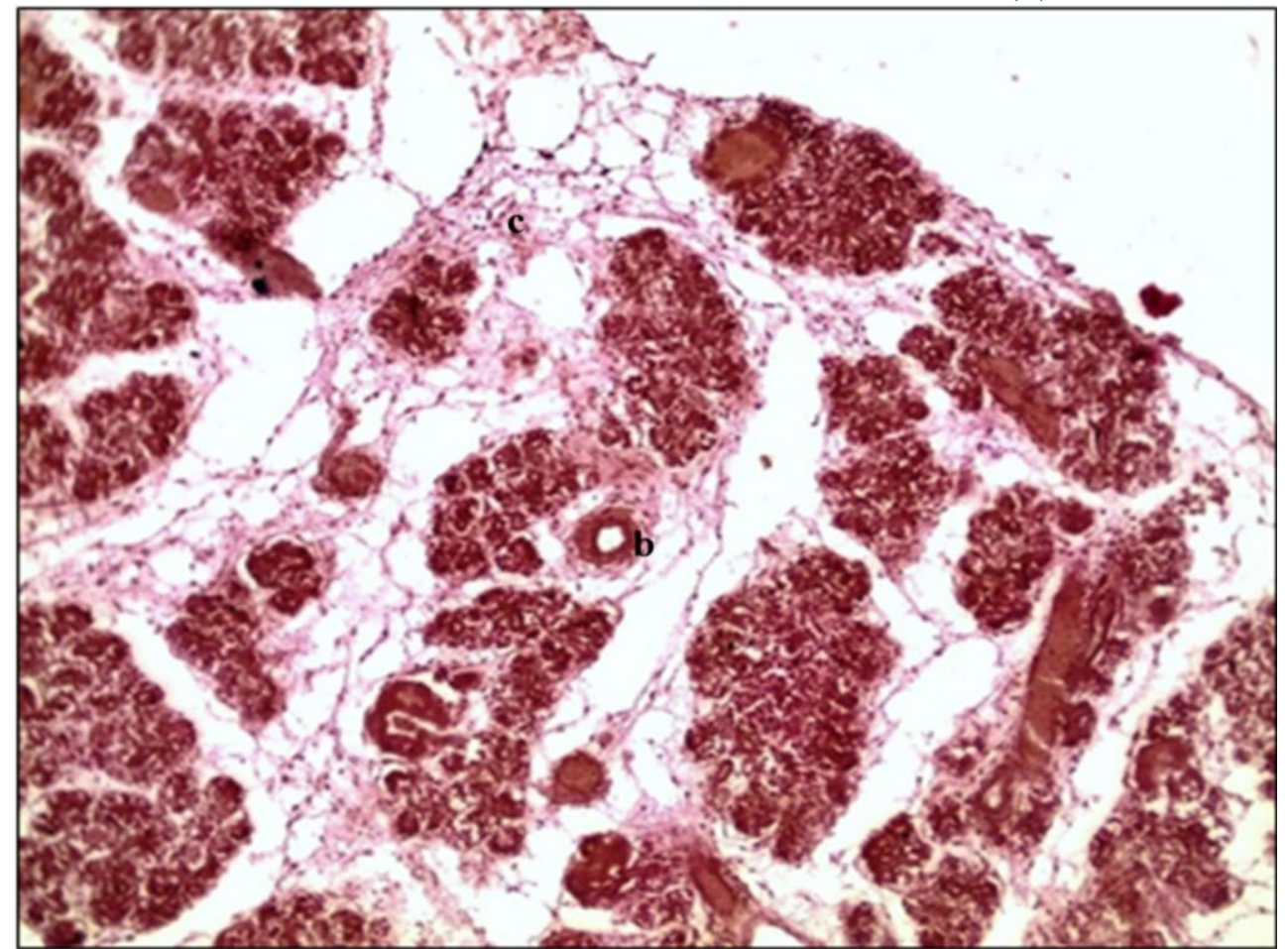

Best carmin`s method $\times 10$

Fig.2 Section of 94 days old goat foetal pancreas showing moderate PAS reaction in islets cells (a), mild to moderate reaction in developing acini (b), and moderate reaction in stromal tissue (c)

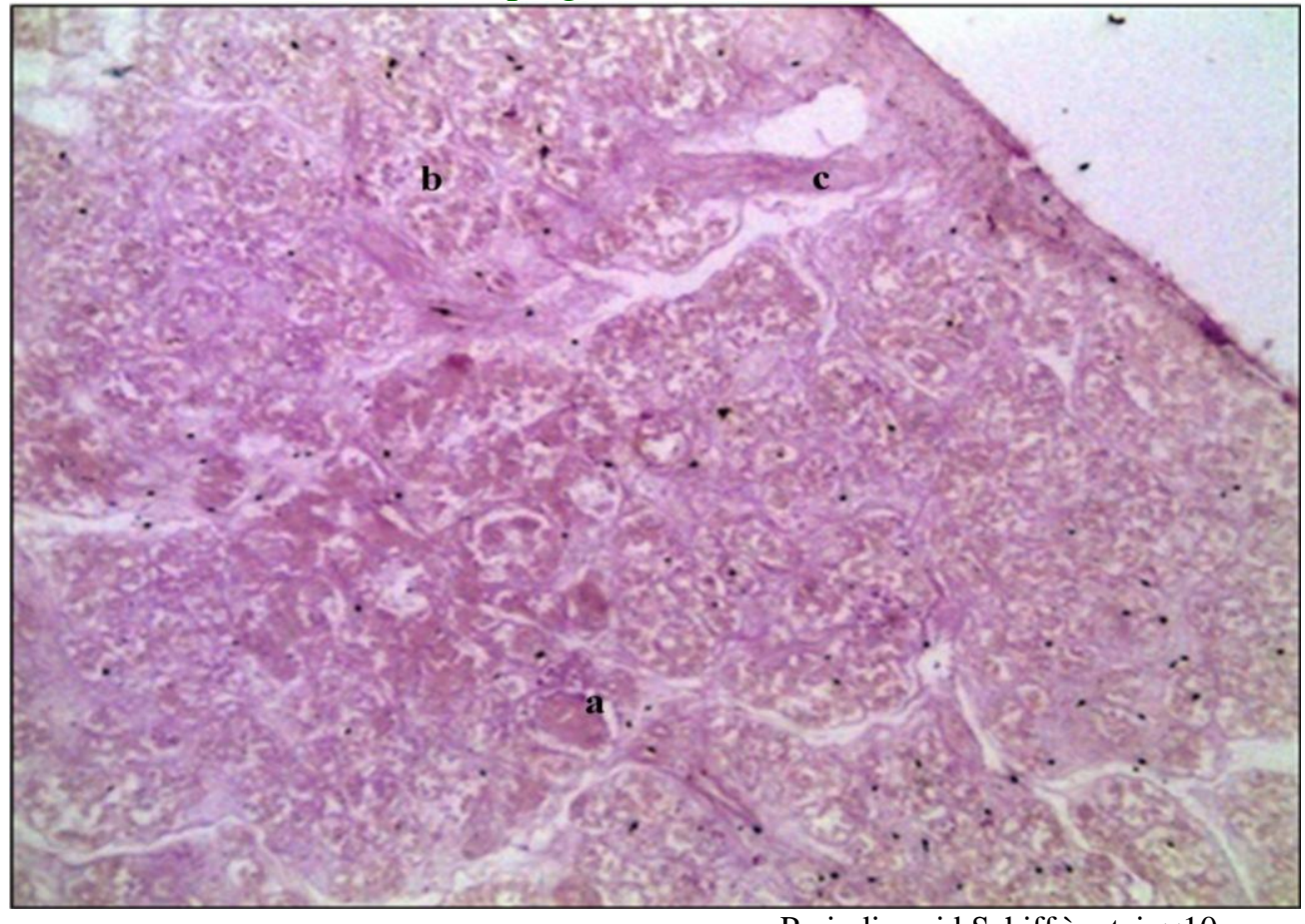

Periodic acid Schiff`s stain $\times 10$ 
Fig.3 Section of 118 days old goat foetal pancreas showing moderate to intense acid mucopolysaccharides reaction in stromal tissue (a), and mild to intense reaction in acinar cells (b)

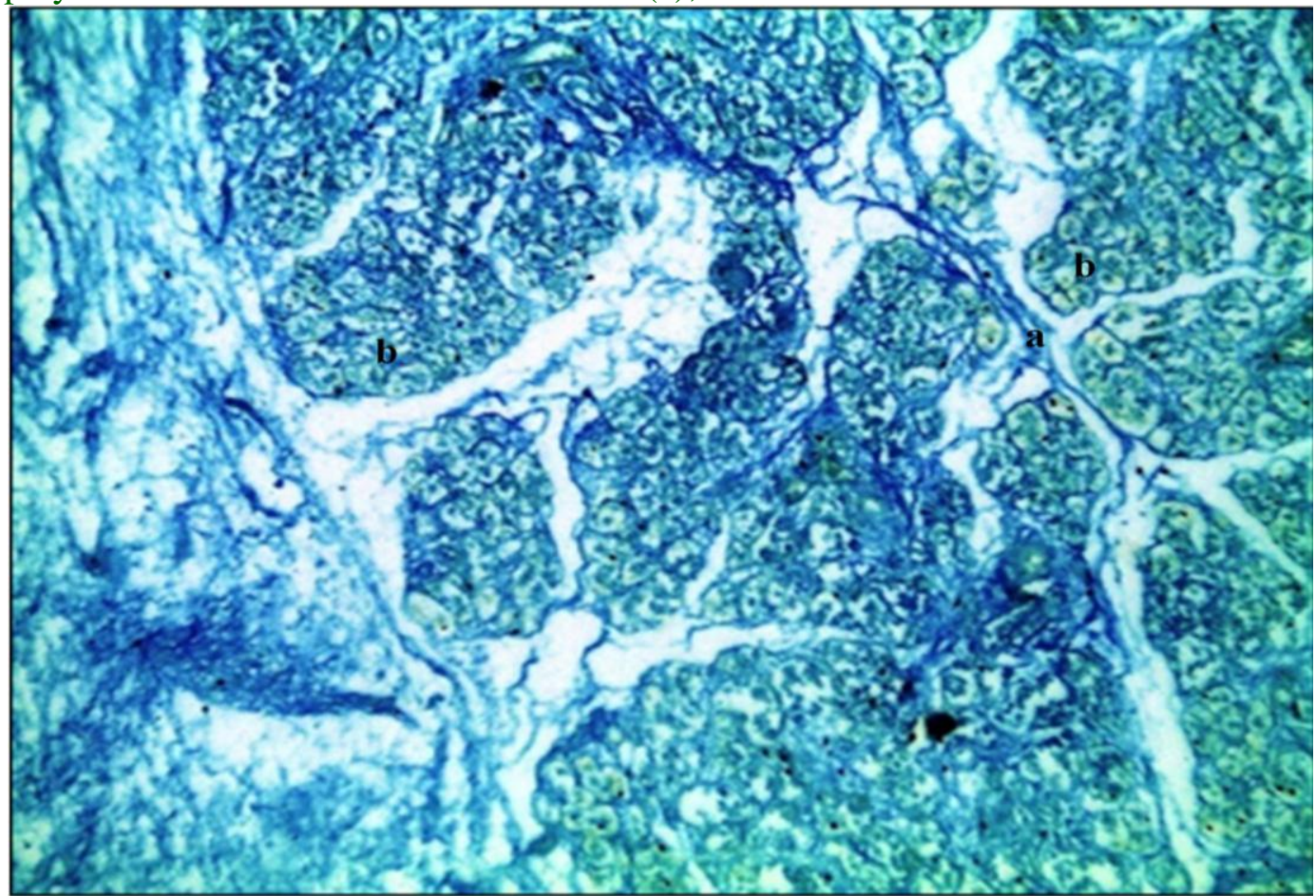

Muller`s colloidal (hydrous) ferric oxide stain $\times 40$

Fig.4 Section of 115 days old goat foetal pancreas showing moderate Sudan black-B reaction in acinar cells (a) and negative reaction in stromal tissue (b)

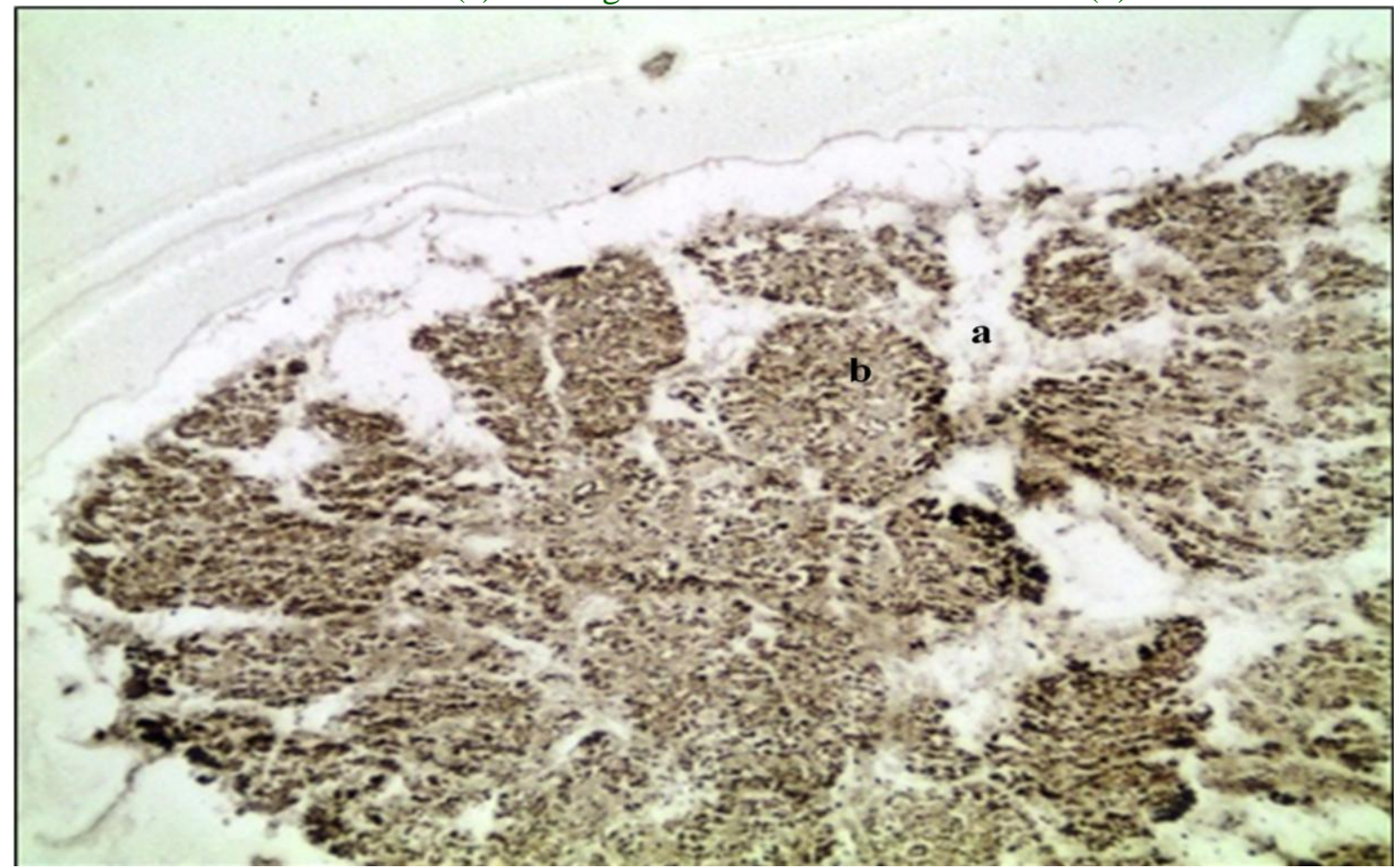

Sudan black-B $\times 10$ 
Fig.5 Section of 118 days old goat foetal pancreas showing positive alkaline phosphate reaction in islets cells (a), acinar cells (b) and pancreatic ducts cells (c)

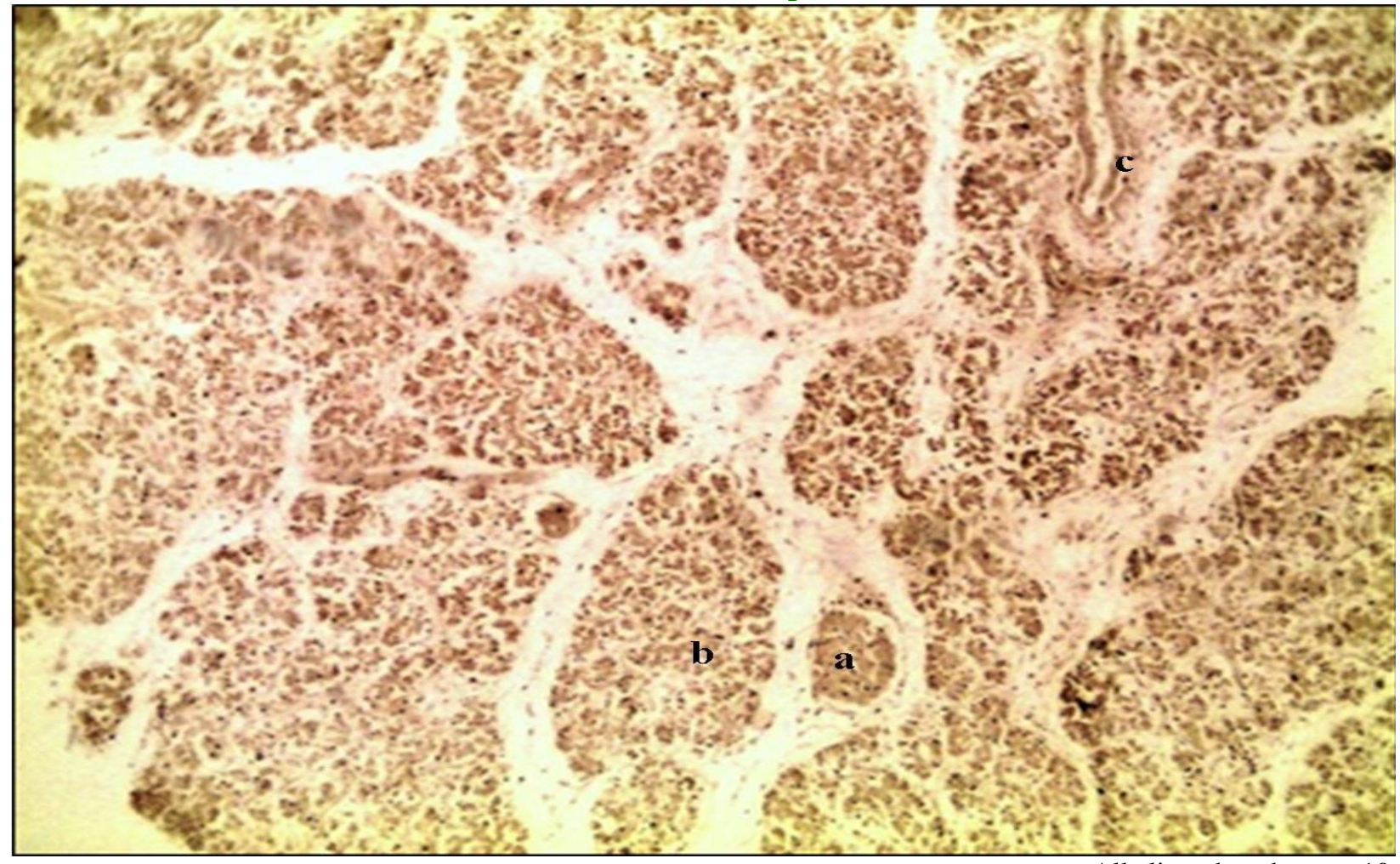

Alkaline phosphatase $\times 10$

Table.1 Histochemical reactions in the pancreas of goat in mid and late prenatal periods

\begin{tabular}{|c|c|c|c|c|c|c|c|}
\hline \multirow{2}{*}{\multicolumn{2}{|c|}{$\begin{array}{l}\text { Components of } \\
\text { pancreas }\end{array}$}} & \multicolumn{6}{|c|}{ Histochemical studies } \\
\hline & & \multirow{2}{*}{$\begin{array}{c}\text { B.CARMIN } \\
++ \\
\end{array}$} & \multirow{2}{*}{$\begin{array}{c}\text { PAS } \\
\text { to++ }\end{array}$} & \multirow{2}{*}{$\begin{array}{c}\text { AMPS } \\
++\end{array}$} & \multirow{2}{*}{$\frac{\text { SB-B }}{+}$} & \multirow{2}{*}{$\frac{\text { AKP }}{-}$} & \multirow{2}{*}{$\frac{\mathbf{A C P}}{-}$} \\
\hline Tubule cells & I & & & & & & \\
\hline & II & ++ & + to+t & ++ & + & - & - \\
\hline \multirow[t]{2}{*}{ Bud cells } & I & ++ to+++ & ++ & ++ & ++ & - & - \\
\hline & II & ++ to +++ & ++ & ++ & ++ & - & - \\
\hline \multirow[t]{2}{*}{ Islets cells } & I & ++ & ++ & ++ to +++ & + & + & - \\
\hline & II & ++ to +++ & ++ to +++ & ++ to +++ & + & + & - \\
\hline \multirow[t]{2}{*}{ Acinar cells } & I & +++ & + to++ & + to+++ & + & + & - \\
\hline & II & ++ & + to++ & + to+++ & ++ & + & - \\
\hline \multirow{2}{*}{$\begin{array}{l}\text { Pancreatic duct } \\
\text { cells }\end{array}$} & I & ++ & ++ & ++ & + to++ & - & - \\
\hline & II & ++ & ++ & ++ & + to++ & - & - \\
\hline \multirow{2}{*}{$\begin{array}{l}\text { Mesenchymal } \\
\text { cells }\end{array}$} & I & ++ & + & +++ & + & + & - \\
\hline & II & ++ & + & +++ & + & + & - \\
\hline \multirow[t]{2}{*}{ Stromal Tissue } & I & + to++ & + to++ & ++ to +++ & -to+ & + to++ & - \\
\hline & II & + to++ & ++ & ++ to +++ & - & + to++ & - \\
\hline \multirow{2}{*}{$\begin{array}{l}\text { Wall of blood } \\
\text { vessels }\end{array}$} & I & +++ & +++ & +++ & ++ & ++ & - \\
\hline & II & +++ & +++ & +++ & ++ & ++ & - \\
\hline
\end{tabular}

Note- (-) Negative, (+) Mild, (++) Moderate, (+++) Intense

I- $\quad$ Mid prenatal period

II- $\quad$ Late prenatal period 
This tissue was processed through alcohol- benzene- paraffin embedding technique and 5 to 6 micron and stained with following methods

\begin{tabular}{|c|l|c|l|}
\hline 1. & Best carmine method & Luna (1968) & For study of glycogen \\
\hline 2. & $\begin{array}{l}\text { Periodic Acid Schiff's } \\
\text { (PAS) method }\end{array}$ & Luna (1968) & For study of Polysaccharides \\
\hline 3. & $\begin{array}{l}\text { Muller's Colloidal } \\
\text { (hydrous) ferric oxide } \\
\text { method }\end{array}$ & Luna (1968) & $\begin{array}{l}\text { For study of acid } \\
\text { mucopolysaccharides }\end{array}$ \\
\hline 4. & $\begin{array}{l}\text { (a) Gomori's method } \\
\text { (b) Modified Gomori's } \\
\text { method after frediction }\end{array}$ & Pearse (1968) & For study of Alkaline phosphatase \\
\hline 5. & Gomori's method & Davenport (1960) & For study of Acid phosphatase \\
\hline 6. & Sudan Black- B method & $\begin{array}{c}\text { Bancroft and } \\
\text { Stevens (1977) }\end{array}$ & For study of lipids \\
\hline
\end{tabular}

Similar to the present findings Conklin (1962) in the foetal pancreas of man reported a decrease in the amount of glycogen in acinar cell buds with the advancement of foetal age. Moreover, Like and Orci (1972) found glycogen in human foetal differentiated exocrine cells of pancreas.

In the present study the cytoplasm of islets cells showed moderate and moderate to intensely positive for glycogen in mid and late prenatal period, respectively. Conklin (1962) stated weak reaction for glycogen in islets cells in the foetal pancreas of man at 12.5 to 14.5 week gestation, however according to Like and Orci (1972) the glycogen was absent in the endocrine cells of human foetal pancreas.

The cytoplasm of foetal goat pancreatic mesenchymal cells, tubular cells, bud cells, acinar cells and pancreatic duct cells showed mild, mild to moderate, moderate, mild to moderate and moderate reaction for PAS positive substances in both mid and late prenatal periods. Conklin (1962) in foetal pancreas of man reported the PAS positive reaction in the basement membrane of pancreatic tubules at 14.5 to 17 weeks gestation. In the present study the PAS positive reaction in the cytoplasm of islets cells and in stromal tissue was relatively more in late prenatal period than mid prenatal period. However, according to Conklin (1962) the intertubular connective tissue was no longer stain with PAS.

The reaction for acid mucopolysaccharides in all foetal goat pancreatic components in late prenatal period was similar to the mid prenatal period (Table 4).

In the cytoplasm of mesenchymal cells, tubules cells, bud cells islets cells, acinar cells and pancreatic duct cells, stromal tissue and blood vessels was intense, moderate, moderate, moderate to intense, mild to intense, moderate, moderate to intense and intense respectively in both groups. According to Conklin (1962) in human foetal pancreas the basement membranes of the tubules and the connective tissue capsules of the islets were positive for colloidal iron from 14.5 to 17 week but the fibers of inter tubular stroma showed slight affinity for colloidal iron at these stages.

In goat foetal pancreas of mid and late prenatal period the mesenchymal cells, tubules cells, bud cells, islets cells, pancreatic duct cells and the wall of blood vessels showed mild, mild, moderate, mild, mild to moderate and moderately positive reaction respectively for lipids. The acinar cells had 
relatively more lipid in late prenatal period than mid prenatal goat where the reaction was mild in mid prenatal period and moderate in late prenatal period. In stromal tissue the lipids were almost absent where trace of these substances was present only in mid prenatal period.

In all histological component of foetal goat pancreas the reaction for alkaline phosphate in late prenatal period was similar to mid prenatal. The mesenchymal cells, islets and acinar cells exhibited mild reactions. Meshram et al., (2002) observed moderate activity of alkaline phosphate in the acini of kids and adult goats whereas in young animals the activity was mild to moderate for this enzyme. The stromal tissue and wall of blood vessels showed mild to moderate and moderate amount of this enzyme, respectively. Meshram et al., (2002) reported week activity of alkaline phosphatese in connective tissue and tunics of blood vessels. According to Latio et al., (1974) the alkaline phosphatase activity was present in the vascular endothelium of human foetal pancreas. The alkaline activity was absent in the cells of pancreatic tubules, buds and ducts of foetal goats. The nuclei of the cells of all component of goat foetal pancreas exhibited mild feulgen reaction in mid and late prenatal periods. The acid Phosphatase activity could not be observed in the pancreas of goat foetus at mid and late prenatal periods. However, Latio et al., (1974) in foetal pancreas of man found acid phosphatase in apical half of acinar cells and in stromal mononuclear cells.

\section{References}

Bancroft, J.D. and Stevens, A.1977. Theory and practice of histological techniques. Churchill Livingstone Edinburgh London and New York.

Conklin, J.A. 1962. Cytogenesis of the human fetal pancreas. American Journal of Anatomy 111: 181-193.

Devenport, H.A. 1960. Histological and histochemical techniques. W.B. Saunders Company, Philadelphia.

Latio, M., Lev, R. and Orlic, D. 1974. The developing human fetal pancreas: An ulrastructural and histochemical study with special reference to exocrine cells. J. Anat. 117, 3, pp.619-634; March, 1974.

Like, A. A., and Orci, L. 1972. Embryogenesis of the pancreatic islets: a light and electron microscopic study. Diabetes 21 (suppl. 2), 511-534.

Luna, L. G. 1968. Manual of histological staining methods of armed forces institute of pathology. $3^{\text {rd }}$ edn. The blakistan Division Mc-Graw Hill Book Company, New York.

Meshram, B. N., Dalvi, R. S., Bhamburkar V. R., Banubakode, S. B., Nandeshwar, N. C. and Karmore, S. K. 2002. Histochemical and histoenzymatic studies of the caprine pancreas. Indian journal of veterinary anatomy. June and December, 2002, (1 and 2): 5-7.

Pearce R. M. 1903. The development of the islands of Langerhans in the human embryo. Am. J. Anat., 2: 445-455.

\section{How to cite this article:}

Dharmendra Singh, Ajay Prakash, M.M. Farooqui, Sri Prakash Singh, Satish K. Pathak and Vijay Kumar. 2017. Histochemical Studies of Pancreas in Prenatal Goat (Capra hircus). Int.J.Curr.Microbiol.App.Sci. 6(8): 1163-1169. doi: https://doi.org/10.20546/ijcmas.2017.608.144 